\title{
PENGARUH VOLUME PENJUALAN DAN BIAYA PRODUKSI KALUNG TERHADAP LABA PADA HIDAYAH SHOP KUTA-BADUNG
}

\author{
Fauzi Dwi Putra \\ Jurusan Pendidikan Ekonomi \\ Universitas Pendidikan Ganesha \\ Singaraja, Indonesia \\ e-mail: jearrkyodjie@gmail.com
}

\begin{abstract}
Abstrak
Penelitian ini bertujuan untuk mengetahui Pengaruh volume penjualan dan biaya produksi baik secara parsial maupun simultan terhadap laba pada hidayah shop kuta-badung. Jenis penelitian ini merupakan penelitian kausal atau sebab akibat. Metode pengumpulan data dalam penelitian ini menggunakan dokumentasi. Metode analisis data menggunakan analisis regresi linier berganda dengan bantuan SPSS 17.0 for windows. Hasil penelitian menunjukan bahwa secara parsial volume penjualan berpengaruh positif dan signifikan terhadap laba pada hidayah shop kuta-badung yang didukung dengan hasil pengujian hipotesis menggunakan t-test bahwa nilai t-hitung > nilai t-tabel $(68,998>1,671)$ sehingga Ha diterima dan biaya produksi berpengaruh positif dan signifikan terhadap laba pada hidayah shop kuta-badung yang didukung dengan hasil pengujian hipotesis menggunakan ttest bahwa nilai t-hitung $>$ nilai t-tabel $(75,370>1,671)$ sehingga Ha diterima, kemudian secara simultan volume penjualan dan biaya produksi berpengaruh positif dan signifikan terhadap laba pada hidayah shop kuta-badung yang didukung dengan hasil pengujian f-test bahwa nilai f-hitung > nilai f-tabel $(3249,570>3,96)$ sehingga Ha diterima.
\end{abstract}

Kata Kunci : Biaya Produksi, Laba dan Volume Penjualan

\begin{abstract}
This study aims to determine the effect of sales volume and production costs either partially or simultaneously to profit in hidayah shop kuta-badung. This type of research is a causal or causal research. Methods of data collection in this study using documentation. Methods of data analysis using multiple linear regression analysis with the help of SPSS 17.0 for windows. The result of research shows that partially sales volume have positive and significant effect to profit at hidayah shop kuta-badung supported with result of hypothesis test using t-test that $t$-hit value $>t$-table value $(68,998>1,671)$ so that $\mathrm{Ha}$ accepted and production cost have positive and significant effect to profit at hidayah shop kuta-badung supported with result of hypothesis test using t-test that t-hit value $>t$-table $(75,370>1,671)$ value so that $\mathrm{Ha}$ accepted, then simultaneously the sales volume and production cost have a positive and significant effect to the profit in hidayah shop kuta-badung supported with the result of f-test that f-count value $>\mathrm{f}$-table value $(3249,570>3,96)$ so that $\mathrm{Ha}$ is accepted.
\end{abstract}

Keywords: Production Cost, Profit and Sales Volume

\section{PENDAHULUAN}

Perusahaan untuk dapat

berkembang haruslah melalui perjuangan

dan didukung dengan perencanaan yang

matang dalam menghadapi berbagai masalah dan rintangan yang timbul, seperti masalah operasional, keuangan, maupun masalah pemasaran dari produk yang diproduksi. Berkembangnya permintaan akan barang dan jasa oleh konsumen, baik 
dalam jumlah maupun jenisnya mendorong perusahaan-perusahaan untuk saling berpacu agar mampu menghasilkan produk yang sesuai dengan kebutuhan konsumen. Keadaan ini mengakibatkan terjadinya persaingan sesama perusahaan yang menghasilkan barang dan jasa yang sejenis. Untuk menghadapi persaingan ini memaksa perusahaan untuk berorientasi pada kegiatan pemasaran. Dalam hal ini perusahaan harus melakukan berbagai macam strategi, baik strategi dalam berproduksi, maupun penetapan harga jual. Salah satu strategi dalam berproduksi adalah menentukan efisiensi biaya produksi.

Perusahaan didirikan bertujuan untuk meningkatkan volume penjualan, mempertinggi daya saing, dan meminimalkan biaya produksi untuk mencapai laba maksimal. Perkembangan perusahaan dan laba yang dicapai perusahaan dapat digunakan sebagai alat ukur terhadap keberhasilan perusahaan dalam menjalankan aktivitas yang berkenaan dengan operasinya. Jika tujuan perusahaan itu tercapai maka kelangsungan hidup perusahaan mampu dipertahankan dan mampu bersaing dengan perusahaan lain.

Pengukuran laba bukan saja penting untuk menentukan prestasi perusahaan tetapi penting juga sebagai informasi bagi pembagian laba dan penentuan kebijakan investasi. Oleh karena itu, laba menjadi informasi yang dilihat oleh banyak orang seperti profesi akuntansi, pengusaha, analis keuangan, pemegang saham, ekonom, fiskus, dan sebagainya (Harahap, 2001: 259). Dengan begitu Laba sangatlah penting untuk kelangsungan perkembangan suatu perusahaan. Laba sendiri di pengaruhi oleh beberapa faktor yaitu Biaya, Harga Jual, Volume penjualan dan Produksi.

Biaya produksi merupakan dasar bagi perusahaan yang memberikan perlindungan bagi perusahaan itu sendiri dari kemungkinan terjadinya kerugian. Kerugian akan mengakibatkan suatu usaha tidak dapat berkembang, bahkan akan dapat memaksa suatu perusahaan untuk menghentikan usahanya. Salah satu cara menghindari hal tersebut adalah dengan memperhitungkan biaya produksi. Dengan menekan biaya produksi, maka harga jual terhadap barang yang akan dipasarkan juga dapat ditekan seminimal mungkin.

Penentuan harga jual yang tidak tepat sering berakibat fatal pada masalah keuangan perusahaan dan akan mempengaruhi kontinuitas usaha perusahaan. Untuk itu setiap perusahaan harus menetapkan harga jualnya secara tepat karena harga merupakan satu-satunya unsur bauran pemasaran yang memberikan pendapatan bagi perusahaan. Pada hakekatnya perusahaan dalam menjual produknya harus dapat mencapai keuntungan yang diharapkan, sehingga perusahaan dalam menjual produknya harus menetapkan harga jual dengan tepat. Tujuan menetapkan harga jual yang sesuai adalah untuk meningkatkan volume penjualan yang diperoleh oleh perusahaan dalam setiap periode. Volume penjualan adalah jumlah unit yang terjual dari suatu produk yang ditetapkan dalam suatu periode tertentu.

Jika volume penjualan pada suatu perusahaan dapat ditingkatkan, itu artinya laba dalam perusahaan tersebut juga akan meningkat. Salah satu tujuan utama perusahaan adalah mencapai tingkat laba atau keuntungan yang maksimal. Karena tanpa adanya suatu pencapaian laba, suatu perusahaan tidak akan dapat melanjutakan usahanya. Selain untuk mencapai tingkat laba yang maksimal, kelangsungan hidup perusahaan dimasa yang akan datang juga harus diperhatikan. Laba adalah selisih dari pendapatan diatas biaya-biayanya dalam jangka waktu (periode) tertentu (Harnato, 2003 : 444).

Dalam sebuah perusahaan fungsi manajemen sangatlah penting, dimana manjemen harus mampu menyusun suatu perencanaan. Dengan perencanaan yang baik dan tepat dapat memperkecil kemugkinan perusahaan mengalami kerugian dan aktivitas perusahaan berjalan dengan baik. Untuk itu, faktor utama yang menentukan kelancaran usaha disuatu perusahaan adalah bagaimana seorang seorang pemimpin dapat merencanakan, mengatur, mengawasi, dan mengambil suatu keputusan secara pasti menangani proses 
Perusahaan Hidayah Shop adalah perusahaan yang bergerak di 'bidang penjualan pernak pernik dari kerangkerangan laut. Dalam penjualannya hidayah shop kerap mengalami kenaikan dan penurunan laba di setiap tahunnya. Perusahaan Hidayah Shop dalam memproduksi menghasilkan lebih dari satu macam produk yaitu : kalung, cincin, gelang, dan segala macam pernak-pernik yang bahan bakunya adalah kerang-kerangan laut. Namun, produk yang dihasilkan oleh perusahaan ini didominasi oleh kalung. Kalung merupakan produk andalan Hidayah Shop serta merupakan produk yang paling diminati oleh pengunjung Hidayah Shop, baik itu wisatawan asing maupun wisatawan domestik. Maka dari itu penelitian yang dilakukan tertuju pada produk andalan Hidayah Shop yaitu kalung. Adapun biaya yang dikeluarkan perusahaan dalam memproduksi kalung terdiri dari, biaya pembelian bahan baku berupa : kerangkerangan laut, biaya tenaga kerja yaitu upah karyawan, serta biaya over head pabrik berupa biaya bahan penolong.

Volume penjualan Hidayah Shop pada tahun 2015 sebesar Rp. 559.603.000, tahun 2016 sebesar Rp. 488.193.000, sedangkan tahun 2017 sebesar Rp. 516.800.000. Biaya produksi tahun 2015 sebesar Rp. 367.644.100, tahun 2016 sebesar Rp. 309.546.200, sedangkan tahun 2017 sebesar Rp. 252.882.000. Laba pada tahun 2015 sebesar Rp. 129.601.900, tahun 2016 sebesar Rp. 113.138.300, sedangkan tahun 2017 sebesar Rp. 194.529.000. Dari data di atas dapat terlihat bahwa volume penjualan pada tahun 2015 dan tahun 2017 mengalami peningkatan, sedangkan tahun 2016 mengalami penurunan. Biaya produksi pada tahun 2015 sampai tahun 2017 mengalami penurunan, sedangkan laba pada tahun 2015 dan tahun 2017 mengalami peningkatan, sedangkan tahun 2016 mengalami penurunan. Hal ini tidak sejalan dengan teori yang dikatan oleh Harnato (2003) bahwa Jika volume penjualan pada suatu perusahaan dapat ditingkatkan, itu artinya laba dalam perusahaan tersebut juga akan meningkat.
Seperti yang sudah dijelaskan sebelumnya dapat diketahui adaya masalah yang dihadapi oleh Hidayah Shop KutaBadung yaitu perkembangan laba bersih pada Hidayah Shop Kuta-Badung dari tahun 2015 ke tahun 2017 tidak mengalami peningkatan yang signifikan seperti yang diharapkan hal itu bisa dilihat dari laporan keuangannya pada tahun 2015-2017 dari bulan Januari sampai bulan Desember yang cenderung mengalami fluktuasi. Walaupun volume penjualan kalung tiap bulannya dari bulan Januari sampai dengan bulan Desember terus mengalami peningkatan, tetapi laba bersih yang diperoleh belum tentu mengalami peningkatan pula, hal ini dikarenakan adanya peningkatan biaya produksi dalam mengolah kalung, dan persaingan yang ketat diantara perusahaan yang sejenis. Menelaah perihal tersebut, maka penulis berkeinginan untuk membuat penelitian yang berjudul Pengaruh Volume Penjualan dan Biaya Produksi Kalung Terhadap Laba Pada Hidayah Shop KutaBadung.

Menurut Swastha (2001:1)
penjualan adalah ilmu dan seni mempengaruhi pribadi yang dilakukan oleh penjual untuk mengajak orang lain agar bersedia membeli barang dan jasa yang ditawarkan. Menurut Winardi (2005:26) penjualan adalah berkumpulnya seorang pembeli dan penjual dengan tujuan melaksanakan tukar menukar barang dan jasa berdasarkan pertimbangan yang berharga misalnya pertimbangan uang.

Pencapaian volume penjualan adalah salah satu hal penting yang harus diperhatikan dalam suatu perusahaan. Volume penjualan merupakan total keseluruhan dari hasil penjualan yang dicapai oleh perusahaan atau badan usaha dari suatu kegiatan pemasaran dalam periode tertentu. Volume penjualan tidak memisahkan secara tunai maupun kredit tetapi dihitung secara keseluruhan dari total yang dicapai. Seandainya volume penjualan meningkat dan biaya distribusi menurun maka tingkat pencapaian laba perusahaan meningkat tetapi sebaliknya bila volume penjualan menurun maka pencapaian laba perusahaan juga menurun. 
Menurut Kotler (2000) volume penjualan adalah barang yang terjual dalam bentuk uang untuk jangka waktu tertentu dan didalamnya mempunyai strategi pelayanan yang baik, sedangkan menurut Swastha \& Irawan (1999:150) volume penjualan merupakan tingkat penjualan maksimum yang dapat dicapai oleh penjual.

Ada beberapa usaha untuk meningkatkan volume penjualan, adalah sebagai berikut. Yang pertama menjajakan produk dengan sedimikian rupa sehingga konsumen melihatnya. Yang kedua menempatkan dan pengaturan yang tertatur sehingga produk tersebut akan menarik perhatian konsumen. Yang ketiga mengadakan analisa pasar. Yang keempat menentukan calon pembeli atau konsumen yang potensial. Yang kelima mengadakan pameran. Yang keenam mengadakan discount atau potongan harga. Adapun indikator dari volume penjualan menurut Kotler (2008), adalah harga, promosi, kualitas, saluran distribusi dan produk. Menurut Saladin (2001) harga merupakan salah tukar yang digunakan untuk mendapatkan produk atau jasa dengan sejumlah uang. Swastha \& Irawan (2005) harga ialah sesuatu yang dibutuhkan untuk mendapatkan suatu kombinasi antara pelayanan ditambah produk dengan membayar jumlah uang yang sudah menjadi patokan. Alma (2002) harga merupakan sebuah nilai yang ditentukan untuk suatu barang maupun jasa yang ditentukan dengan uang. Promosi, menurut ahli pemasaran Harper Boyd : promosi diartikan sebagai upaya membujuk orang untuk menerima produk, konsep dan gagasan. Menurut pakar pemasaran lainnya yaitu Boone dan Kurtz, promosi adalah proses menginformasikan, membujuk, dan mempengaruhi suatu keputusan pembelian. Kualitas, menurut Elliot, pengertian kualitas ialah sesuatu yang berbeda untuk orang yang berbeda dan tergantung pada waktu dan tempat atau dikatakan sesuai dengan tujuan. Menurut Crosby, pengertian kualitas adalah kesesuaian dengan kebutuhan yang meliputi availability, delivery, reliability, maintainability dan cost effectiveness. Sedangkan pengertian kualitas menurut Goetch dan Davis, kualitas adalah suatu kondisi dinamis yang berkaitan dengan produk, pelayanan, orang, proses dan lingkungan yang memenuhi atau melebihi apa yang diharapkan. Saluran distribusi, menurut Kotler \& Keller (2010) saluran distribusi adalah organisasi-organisasi yang saling tergantung yang tercakup dalam proses yang membuat produk atau jasa menjadi tersedia untuk digunakan atau dikonsumsi. Menurut Alma (2007) saluran distribusi merupakan lembaga yang saling terkait untuk menjadi produk atau jasa siap digunakan atau dikonsumsi. Menurut Tjiptono (2008) saluran distribusi dapat diartikan sebagai kegiatan pemasaran yang berusaha memperlancar dan mempermudah penyampaian barang dan jasa dari produsen kekonsumen, sehingga penggunaannya sesuai dengan yang diperluas (jenis, jumlah, harga, tempat dan saat dibutuhkan). Menurut Goleman (2003) saluran distribusi adalah serangkaian dari organisasi yang saling bergantung yang memudahkan pemindahan kepemilikan sebagaimana produk-produk bergerak dari produsen ke pengguna atau pelanggan. Produk, pengertian produk menurut Fandy Tjiptono (2008) Produk adalah segala sesuatu yang ditawarkan produsen untuk diperhatikan, diminya, dicari, dibeli, digunakan atau dikonsumsi pasar sebagai pemenuhan kebutuhan atau keinginan pasar yang bersangkutan. Pengertian produk menurut Swastha \& Irawan (1990:165) produk adalah suatu sifat kompleks, baik dapat diraba maupun tidak diraba, termasuk bungkus, warna, harga, prestise perusahaan, pelayanan pengusaha dan pengecer, yang diterima pembeli untuk memuaskan keinginan dan kebutuhan. Sedangkan pengertian produk menurut Kotler \& Amstrong (2001:346) produk adalah segala sesuatu yang ditawarkan, dimiliki, digunakan atau pun dikonsumsi sehingga mampu memuaskan keinginan dan kebutuhan termasuk di dalamnya berupa fisik, tempat, orang, jasa, gagasan, serta organisasi. Sedangkan menurut Alamiah \& Padji (2003:126) 
indikator volume penjualan sebagai berikut. Volume penjualan $=$ Total penjualan

Volume penjualan adalah ukuran yang menunjukan banyaknya atau besarnya jumlah barang atau jasa yang terjual. Menurut Swastha \& Irawan (2005) ada beberapa faktor yang mempengaruhi volume penjualan, yaitu: yang pertama kondisi dan kemampuan pasar. Kondisi dan kemampuan penjual sangat menentukan keyakinan seseorang untuk membeli produk yang dipasarkan. Kondisi pasar yang harus diperhatikan antara lain yaitu jenis dan karakteristik barang yang ditawarkan, harga pokok, dan syarat penjualan seperti pembayaran, penghantaran, pelayanan sesudah penjualan, garansi dan sebagainya. Yang kedua kondisi pasar. Pasar merupakan sasaran dalam menjual suatu produk, dengan demikian pasar juga akan mempengaruhi tingkat penjualan untuk dapat meningkatkan volume penjualan. Kondisi pasar yang harus diperhatikan yaitu jenis pasar, kelompok pembeli atau segmen pasarnya, daya belinya, frekuensi pembelinya, dan keinginan serta kebutuhan pembelinya. Yang ketiga modal. Dalam menjual barang atau produk haruslah produk tersebut dikenal oleh calon pembeli, apabila berada jauh dari penjual maka haruslah si penjual memperkenalkan produknya kepada pembeli. Untuk mencapai tujuan tersebut diperlukan sarana dan prasarana seperti : dana promosi, alat transportasi maupun sarana pendukung lainnya. Semua ini hanya dapat dilakukan apabila penjual memiliki sejumlah modal yang diperlukan untuk melaksanakan aktivitas tersebut. yang keempat kondisi organisasi pasar. Dalam suatu perusahaan besar, kegiatan penjualan biasanya ditangani oleh bagian yang berwenang yaitu bagian penjualan dan pemasaran. Namun pada perusahaan kecil, kegiatan penjualan biasanya ditangani oleh orang yang juga melakukan fungsi-fungsi lain. Hal ini disebabkan karena jumlah tenaga kerjanya lebih sedikit dan sistem organisasinya lebih sederhana. Yang kelima faktor lain. Faktor lain disini adalah pendukung dari pemasaran suatu barang, misalnya periklanan, peragaan, kampanye, pemberian hadiah. Hal ini sangat tergantung pada kondisi serta situasi perusahaan dan pembeli.

Adapun cara yang digunakan untuk meningkatkan volume penjualan, antara lain: yang pertama promosi penjualan. Merupakan salah satu aspek yang penting dalam manajemen pemasaran, perusahaan memberitahukan atau mempromosikan produk-produknya melalui media-media yang ada. Yang kedua meningkatkan kualitas produk. Dalam meningkatkan volume penjualan, perusahaan menjaga dan meningkatkan kualitas produk yang dipasarkannya, supaya pembeli merasa puas membeli produk yang dipasarkan, bahkan dapat menjadi pelanggan tetap. Hal tersebut dapat meningkatkan volume penjualan perusahaan. Yang ketiga menambahkan keanekaragaman produk yang dijual. Dengan cara ini semakin banyak produk yang ditawarkan, sehingga semakin banyak konsumen dalam membeli barang, dan akibatnya volume penjualan akan meningkat.

Biaya merupakan salah satu kunci keberhasilan perusahaan dalam menjalankan usahanya. Hal ini karena biaya sangat menentukan keuntungan yang akan diperoleh perusahaan. Menurut Supriyono \& Riyanto (1992:45) Biaya adalah harga perolehan yang dikorbankan atau digunakan dalam rangka memperoleh penghasilan atau revenue yang akan dipakai sebagai pengurang penghasilan.

$\begin{array}{ccc}\text { Menurut Mulyadi (2007:8) } & \text { Biaya } \\ \text { adalah pengorbanan } & \text { sumber }\end{array}$ ekonomis yang diukur dalam satuan uang, yang telah terjadi, sedang terjadi atau yang kemungkinan akan terjadi untuk tujuan tertentu. Sedangkan menurut Mardiasmo (1999:48) biaya merupakan pengorbanan ekonomis yang diperlukan untuk memperoleh barang dan jasa.

Kegiatan Produksi adalah hal penting yang harus diperhatikan dalam suatu perusahaan, karena kegiatan produksi merupakan salah satu faktor yang akan mempengaruhi keberhasilan suatu perusahaan. Suatu perusahaan dalam kegiatan produksinya diharapkan dapat 
memproduksi barang secara tepat guna, dalam artian barang yang yang diproduksi oleh perusahaan tersebut dapat memenuhi keinginan pasar. Menurut Jatmiko (2005:128) produksi adalah semua aktivitas yang menambah nilai guna barang atau produk.

Menurut Nurdin dkk (2008:259) produksi adalah semua kegiatan yang menghasilkan atau meningkatkan nilai guna suatu barang atau jasa untuk memenuhi kebutuhan manusia. Kegiatan produksi tidak akan dapat berjalan tanpa adanya faktor-faktor produksi atau sumber daya ekonomi. Ada empat faktor produksi, yaitu: yang pertama faktor produksi alam. Faktor produksi alam atau sumber daya alam adalah segala yang disediakan oleh alam baik langsung maupun tidak langsung yang dapat digunakan manusia memenuhi kebutuhan untuk mencapai kemakmuran. Yang kedua faktor produksi tenaga kerja. Tenaga kerja atau sumber daya manusia adalah segala kegiatan manusia baik fisik maupun rohani yang ditunjukan untuk keperluan produksi. Yang keempat faktor produksi modal. Modal adalah segala sesuatu yang dapat digunakan untuk menghasilkan barang atau jasa selanjutnya. Yang keempat faktor produksi kewirausahaan. Faktor produksi kewirausahaan adalah kemampuan manusia untuk mengelola atau mengendalikan usaha untuk memperoleh laba.

Untuk menghasilkan produk berupa barang diperlukan faktor-faktor produksi seperti bahan baku, bahan pembantu, mesin, tenaga kerja serta keahlian pengusaha. Semua faktor produksi tersebut harus dikorbankan dalam proses produksi untuk menghasilkan barang. Dan pengusaha harus memperhitungkan semua pengorbanan tersebut sebagai biaya produksi. Sebagian ahli berpendapat bahwa biaya produksi adalah semua pengorbanan untuk menghasilkan barang sampai barang atau jasa tersebut tiba di pasar atau sampai ke tangan konsumen.

Biaya produksi adalah semua pengeluaran perusahaan untuk memperoleh faktor-faktor produksi yang digunakan untuk menghasilkan barang- barang produksi oleh perusahaan tersebut. Menurut Halim (1996:5) Biaya produksi yakni biaya-biaya yang berhubungan langsung dengan produksi dari suatu produk dan akan dipertemukan (dimatchkan) dengan penghasilan (revenue) di periode mana produk itu di jual. Menurut Mulyadi (2007:14) Biaya produksi merupakan biaya-biaya yang terjadi untuk mengolah bahan baku menjadi produk jadi yang siap untuk dijual.

Dalam memproduksi suatu barang, faktor terpenting yang harus diperhatikan yaitu biaya yang digunakan untuk memproduksi barang tersebut. Biaya produksi merupakan biaya-biaya yang dikeluarkan untuk pengolahan bahan baku menjadi barang jadi. Adapun indikator biaya produksi, sebagai berikut. yang pertama biaya langsung terhadap produksi. Merupakan semua biaya yang langsung dapat dikaitan dengan barang yang dihasilkan atau langsung dibebankan pada harga pokoknya. Biaya produksi langsung terdiri dari. Pertama, Biaya bahan baku langsung, yaitu semua jenis bahan baku yang merupakan bagian dari produk yang dihasilkan. Jadi biaya ini dapat dikalkulasikan langsung dalam harga pokok tiap macam barang. Kedua, biaya upah langsung, yaitu uapah yang dibayar bagi para pekerja pabrik yang berkaitan langsung dengan produksi sehingga besarnya dapat dibebankan langsung ke harga pokok produk tersebut. Yang kedua biaya produksi tidak langsung. Merupakan biaya-biaya produksi yang tidak dapat secara langsung dikalkulasikan ke dalam harga pokok barang yang diproduksi. Biaya produksi tidak langsung terdiri dari. Pertama, biaya bahan tidak langsung, misalnya yaitu : bahan penolong. Kedua, biaya tenaga kerja tidak langsung, yaitu : gaji atau upah yang sukar untuk dibebankan langsung kepada produk yang termasuk dalam biaya ini. Misalnya, biaya gaji supervisor atau mandor, gaji manajer, dan lain-lain. Ketiga, biaya overhead pabrik, yaitu seluruh biaya produksi yang tidak dapat diklarifikasikan sebagai biaya bahan baku langsung atau biaya tenaga kerja langsung. Keempat, biaya produksi tidak langsung lainnya, yaitu biaya 
penyusutan mesin dan bangunan pabrik, biaya asuransi.

Biaya produksi merupakan biaya-biaya yang dikeluarkan dalam pengolahan bahan baku menjadi produk jadi atau biaya-biaya yang dikeluarkan dalam proses produksi. Menurut Mulyadi (2012) biaya produksi yang dikeluarkan oleh perusahaan dipengaruhi oleh beberapa faktor, dimana faktor tersebut yang nantinya dapat menentukan besar kecilnya biaya yang harus dikeluarkan perusahaan untuk proses produksinya. Dalam buku Pemasaran Barang dan Jasa dikemukakan bahwa faktor-faktor yang mempengaruhi biaya produksi antara lain: yang pertama biaya bahan baku. Biaya bahan baku yaitu biaya yang terjadi sebagai harga perolehan dari bahan baku yang dipakai dalam proses produksi dan berkaitan langsung dengan produk yang dihasilkan. Yang kedua biaya tenaga kerja. Biaya tenaga kerja yaitu semua balas jasa yang diberikan perusahaan kepada karyawan pabrik yang langsung berkaitan dengan proses produksi dan merupakan bagian integral dari produk tertentu. Yang ketiga biaya overhead pabrik. Biaya overhead pabrik yaitu biaya produksi selain biaya bahan baku dan biaya tenaga kerja langsung, yaitu biaya bahan penolong. Biaya tenaga kerja tidak langsung yaitu biaya penyusutan dan amortisasi aktiva tetap pabrik, biaya reparasi dan pemeliharaan aktiva tetap pabrik, biaya listrik dan air pabrik, biaya asuransi pabrik dan biaya overhead lain-lain (Rismiati \& Suratno, 2001:231).

Tujuan utama perusahaan adalah memaksimalkan laba. Laba merupakan indikator prestasi atau kinerja perusahaan yang besarnya tampak di laporan keuangan, tepatnya laba rugi. Tingkat prestasi perusahaan ditunjukan oleh berapa besarnya laba yang diperoleh suatu perusahaan. Pengukuran laba juga digunakan sebagai informasi bagi pembagian laba dan penentuan kebijakan investasi.

Menurut Mulyadi (2002:166) laba adalah sesuatu yang diperoleh dengan mempertemukan penghasilan dalam suatu periode tertentu dengan biaya-biaya yang dikeluarkan atau yang terjadi dalam waktu yang sama tetapi berhubungan dengan realitas penghasilan, Sedangkan menurut Handoko (2002:107) bahwa laba merupakan kelebihan harga jual atas harga pokok/untuk suatu perusahaan secara keseluruhan, merupakan kelebihan pendapatan atas seluruh beban.

Adapun indikator dari laba menurut Halim \& Supomo (2005), adalah sebagai berikut. Yang pertama pendapatan. Menurut Suroto (2000) pendapatan adalah Pendapatan merupakan sumber penghasilan seseorang untuk memenuhi kebutuhan sehari - hari dan sangat penting artinya bagi kelangsungan hidup dan penghidupan seseorang secara langsung mau pun tidak langsung. Sedangkan menurut Antonio (2001) pendapatan adalah kenaikan kotor dalam asset atau penurunan dalam lialibilitas atau gabungan dari keduanya selama periode yang dipilih oleh pernyataan pendapatan yang berakibat dari investasi yang halal, keuntungan, seperti manajemen rekening investasi terbatas. Yang kedua biaya. Menurut Supriyono (1999) biaya adalah harga perolehan yang dikorbankan atau yang digunakan dalam rangka memperoleh penghasilan (revenue) dan akan di pakai sebagai pengurang penghasilan. Menurut Mulyadi (2012) dalam arti luas biaya adalah pengorbanan sumber ekonomis, yang di ukur dalam satuan uang, yang terjadi atau yang kemungkinan akan terjadi untuk mencapai tujuan tertentu. Dalam arti sempit diartikan sebagai pengorbanan sumber ekonomi untuk memperoleh aktiva yang di sebut dengan istilah harga pokok, atau dalam pengertian lain biaya merupakan bagian dari harga pokok yang dikorbankan di dalam suatu usaha untuk memperoleh penghasilan. Menurut Simamora (2000:25) rumusan untuk menghitung laba bersih adalah sebagai berikut. Laba Bersih = Laba sebelum pajak - Pajak penghasilan.

Laba merupakan kenaikan kekayaan atau aktiva yang dimiliki oleh suatu perusahaan. Ada dua unsur-unsur laba, yaitu: yang pertama penghasilan (income) yang diartikan sebagai kenaikan manfaat ekonomi dalam bentuk pemasukan atau peningkatan aktiva atau penurunan kewajiban perusahaan selama periode 
tertentu. Dapat di klasifikasikan menjadi: pertama, pendapatan (revenue), yaitu penghasilan yang timbul dalam pelaksanaan aktivitas biasa dan yang dikenal dengan sebutan yang berbeda, seperti misalnya penjualan barang dagang, penghasilan jasa (fees), pendapatan bunga, pendapatan deviden, royalitas dan sewa. Kedua, keuntungan (gains), yaitu pos lain yang memenuhi definisi penghasilan dan mungkin timbul atau tidak timbul dalam pelaksanaan aktivitas perusahaan yang rutin misalnya pos yang timbul dalam pengalihan aktiva lancer, revaluasi sekuritas, kenaikan jumlah aktiva jangka panjang. yang kedua beban (expense) yang diartikan sebagai penurunan manfaat ekonomi dalam bentuk arus keluar, penurunan aktiva atau kewajiban perusahaan selama periode tertentu. Dapat di klasifikasikan menjadi: pertama, beban yang timbul dalam pelaksanaan aktivitas perusahaan yang biasa, yang meliputi misalnya harga pokok penjualan, gaji dan upah, penyusutan. Kedua, kerugian yang mencerminkan pos lain yang memenuhi definisi beban yang timbul atau tidak timbul dari aktifitas perusahaan yang jarang terjadi, seperti misalnya rugi karena bencana kebakaran, banjir atau pelepasan aktiva tidak lancer (Hanafi \& Halim, 2003:69).

Faktor-faktor yang mempengaruhi laba menurut Mulyadi (2001:513), yaitu: yang pertama biaya. Biaya yang timbul dari perolehan atau mengolah suatu produk atau jasa akan mempengaruhi harga jual produk yang bersangkutan. Yang kedua harga jual. Harga jual produk atau jasa akan mempengaruhi besarnya volume penjualan produk atau jasa yang bersangkutan. Yang ketiga volume penjualan dan produksi. Besarnya volume penjualan berpengaruh terhadap volume produksi produk atau jasa tersebut, selanjutnya volume produksi akan mempengaruhi besar kecilnya biaya produksi.

Berdasarkan pendahuluan di atas maka tujuan dari penelitian ini adalah untuk mengetahui pengaruh volume penjualan dan biaya produksi kalung terhadap laba pada Hidayah Shop Kuta-Badung tahun 20152017.

\section{METODE}

Jenis penelitian yang digunakan adalah jenis penelitian kausalitas yang bertujuan untuk menemukan hubungan sebab-akibat antara volume penjualan dan biaya produksi kalung terhadap laba pada hidayah shop kuta-badung tahun 2015-2017 baik secara parsial maupun secara simultan.

Sumber data yang digunakan adalah data primer. Data primer adalah sumber data yang diperoleh langsung dari sumbernya, data yang dihasilkan berupa data kuantitatif. Dimana data ini adalah jumlah volume penjualan, biaya produksi serta laba dalam setahun pada Hidayah Shop Kuta Badung.

Dalam penelitian ini metode yang digunakan untuk pengumpulan data adalah metode dokumentasi berupa laporan keuangan yang berkaitan dengan volume penjualan, biaya produksi dan laba.

Data hasil penelitian yang telah dikumpulkan melalui metode dokumentasi, sehingga perlu pengolahan data lebih lanjut, untuk mendapatkan kesimpulan sesuai dengan tujuan penelitian yang telah ditetapkan sebelumnya. Analisis data yang digunakan dalam penelitian ini adalah analisis regresi linier berganda.

\section{HASIL DAN PEMBAHASAN Hasil}

Pengaruh volume penjualan terhadap laba pada hidayah shop kutabadung dianalisis dengan menggunakan uji t dengan bantuan program SPSS 17.0 for windows. Hasil analisis tersebut menunjukan bahwa adanya pengaruh volume penjualan terhadap laba secara parsial. variabel volume penjualan secara parsial berpengaruh signifikan terhadap laba, hal ini dapat dilihat pada nilai $p$-value = $0,034<a=0,05$ yang berarti bahwa $\mathrm{Ha}$ diterima dan Ho di tolak.

Pengaruh biaya produksi terhadap laba pada hidayah shop kuta-badung dianalisis dengan menggunakan uji t dengan bantuan program SPSS 17.0 for windows. Hasil analisis tersebut menunjukan bahwa adanya pengaruh biaya produksi terhadap laba secara parsial. variabel biaya produksi secara parsial berpengaruh signifikan terhadap laba, hal ini dapat dilihat pada nilai 
$p$-value $=0,001<a=0,05$ yang berarti bahwa Ha diterima dan Ho ditolak.

Pengaruh volume penjualan, biaya produksi terhadap laba dianalisis menggunakan uji $\mathrm{F}$ dengan bantuan program SPSS 17.0 for windows. Hasil analisis tersebut menunjukan adanya pengaruh volume penjualan, biaya produksi terhadap laba. pengujian dengan menggunakan uji $\mathrm{F}$ yang menunjukan bahwa $p$-value $=0,000<a=0,05$. Maka Ho ditolak dan Ha diterima.

Untuk mengetahui besarnya pengaruh volume penjualan, biaya produksi terhadap laba pada hidayah shop kutabadungdapat diketahui melalui hasil koefisien determinasi (Adjusted $R$ Square). Diketahui bahwa nilai Adjusted $R$ Square yaitu sebesar 0,995 atau sebesar 99,5\%. Nilai tersebut menggambarkan bahwa sumbangan pengaruh volume penjualan $\left(\mathrm{X}_{1}\right)$, biaya produksi $\left(\mathrm{X}_{2}\right)$ terhadap laba $(\mathrm{Y})$ pada hidayah shop kuta-badung sebesar $99,5 \%$ dan sisanya sebesar $0,05 \%$ merupakan sumbangan variabel lain

\section{Pembahasan}

Berdasarkan hasil penelitian menunjukan bahwa secara parsial volume penjualan berpengaruh terhadap laba pada hidayah shop kuta-badung sebesar 0,973 yang didukung hasil pengujian hipotesis dengan uji t-test didapatkan bahwa t-hitung $>$ t-tabel $(68,998>1,671)$ sehingga hipotesis diterima yakni "volume penjualan berpengaruh positif dan signifikan terhadap laba pada hidayah shop kuta-badung". Hasil ini sejalan dengan teorinya yang dikemukakan oleh Rahardjo (2000:33), bahwa adanya hubungan yang erat mengenai Volume Penjualan terhadap peningkatan Laba Bersih perusahaan. Dalam hal ini dapat terlihat dari laporan laba rugi yang dimiliki oleh perusahaan, karena laba akan timbul jika penjualan produk lebih besar dibandingkan dengan biaya-biaya yang dikeluarkan.

Berdasarkan hasil penelitian menunjukan bahwa secara parsial biaya produksi berpengaruh terhadap laba pada hidayah shop kuta-badung sebesar 0,938 yang didukung hasil pengujian hipotesis dengan uji t-test didapatkan bahwa t-hitung
$>$ t-tabel $(75,370>1,671)$ sehingga hipotesis diterima yakni "biaya produksi berpengaruh positif dan signifikan terhadap laba pada hidayah shop kuta-badung". Hasil ini sejalan dengan teorinya yang dikemukakan oleh Carter (2008:129) yang menyatakan bahwa tingkat laba yang diperoleh perusahaan dapat ditentukan oleh volume produksi yang dihasilkan, semakin banyak volume produksi yang dicapai maka semakin tinggi pula biaya produksi. Semakin banyak volume produksi yang dicapai maka semakin tinggi pula laba yang diperoleh. Jadi ketika perusahaan meningkatkan volume produksinya, maka otomatis membutuhkan biaya produksi yang banyak atau biaya produksi akan mengalami peningkatan. Dengan adanya peningkatan biaya produksi, berimplikasi pada jumlah produk yang dihasilkan juga meningkat sehingga produk yang siap atau tersedia untuk dijual juga bertambah. Akibatnya volume penjualanpun ikut bertambah, dan akan mengakibatkan laba yang dihasilkan akan mengalami peningkatan. Jadi secara tidak langsung biaya produksi bertambah mengakibatkan bertambahnya pula laba yang diperoleh oleh perusahaan.

Berdasarkan hasil penelitian

menunjukan bahwa secara simultan volume penjualan dan biaya produksi berpengaruh terhadap laba pada hidayah shop kutabadung yang ditunjukan oleh nilai determinasi sebesar 99,5\% kemudian didukung dengan hasil pengujian hipotesis dengan uji f-test didapatkan bahwa f-hitung $>$ f-tabel $(3249,570>3,96)$ sehingga hipotesis diterima yakni "volume penjualan dan biaya produksi berpengaruh positif dan signifikan terhadap laba pada hidayah shop kuta-badung".

Hal ini sejalan dengan penelitian terdahulu yang dilakukan oleh Sumayah (2011) dan Suzanti (2009) bahwa volume penjualan dan biaya produksi berpengaruh positif dan signifikan terhadap laba. Tingkat keberhasilan atau prestasi perusahaan ditunjukan oleh besarnya laba yang diperoleh suatu perusahaan. Mulyadi (2007) ukuran perstasi kegiatan pemasaran terletak pada kenaikan volume penjualan. Apabila volume penjualan lebih besar dari biaya produksi yang dikeluarkan untuk 
memproduksi suatu barang, itu artinya perusahaan memperoleh laba atau tingkat prestasi perusahaan tersebut meningkat. Sebaliknya, jika volume penjualan lebih kecil dari biaya produksi yang dikeluarkan, maka itu artinya perusahaan mengalami kerugian atau penurunan prestasi.

\section{SIMPULAN DAN SARAN Simpulan}

Berdasarkan hasil penelitian dan pembahasan di atas, maka dapat diambil simpulan sebagai berikut. Pertama volume penjualan berpengaruh positif dan signifikan terhadap laba pada hidayah shop kutabadung yang didukung dengan hasil pengujian hipotesis menggunakan uji t-test bahwa nilai $T=2,207$ dengan nilai $p$-value $=$ $0,034<0,05$ sehingga hipotesis diterima yakni "volume penjualan berpengaruh positif dan signifikan terhadap laba pada hidayah shop kuta-badung". Kedua biaya produksi berpengaruh positif dan signifikan terhadap laba pada hidayah shop kuta-badung yang didukung dengan hasil pengujian hipotesis menggunakan uji t-test bahwa nilai $\mathrm{T}=$ 3,511 dengan nilai $p$-value $=0,001<a=$ 0,05 sehingga hipotesis diterima yakni "biaya produksi berpengaruh positif dan signifikan terhadap laba pada hidayah shop kuta-badung". Ketiga volume penjualan dan biaya produksi berpengaruh positif dan signifikan terhadap laba pada hidayah shop kuta-badung yang didukung dengan hasil pengujian f-test bahwa nilai $F=3249,570$ dengan nilai $p$-value $=0,000<a=0,05$ sehingga hipotesis diterima yakni "volume penjualan dan biaya produksi berpengaruh positif dan signifikan terhadap laba pada hidayah shop kuta-badung".

\section{Saran}

Sesuai dengan simpulan di atas, maka dapat diajukan saran-saran sebagai berikut. Pertama Hidayah Shop KutaBadung diharapkan untuk dapat membuat perencanaan mengenai biaya produksi dengan sebaik-baiknya agar biaya produksi dapat ditekan sekecil mungkin sehingga perolehan laba menjadi optimal, karena berdasarkan hasil penelitian, biaya produksi mempunyai pengaruh yang negatif terhadap laba. Artinya semakin besar biaya produksi yang dikeuarkan maka semakin kecil laba yang diperoleh demikian pula sebaliknya. Untuk menigkatkan volume penjualannya diharapkan Hidayah Shop Kuta-Badung lebih ditingkatkan kegiatan distribusi, promosi dan meningkatkan mutu produknya, karena terbukti memberi pengaruh positif terhadap laba perusahaan. Kedua bagi mahasiswa lain yang berminat meneliti masalah pengaruh volume penjualan dan biaya produksi terhadap laba agar mengembangkan penelitian ini lebih lanjut dan mempertimbangkan variabel lain yang belum diuji dalam penelitian ini yang memiliki pengaruh terhadap laba.

\section{DAFTAR PUSTAKA}

Alamiah \& Padji. 2003. Kamus Istilah Akuntansi. Bandung: Yrama Widya

Antonio, muhammad Syafi'i. 2001. Bank Syariah Dari Teori ke Praktik. Jakarta: Gema Insani Press

Alma, Buchari. 2002. Manajemen Pemasaran dan Pemasaran Jasa. Bandung: CV. Alfabeta

--------. 2007. Manajemen Pemasaran \& Pemasaran Jasa. Edisi Revisi. Bandung: CV. Alfabeta

Carter.K William. 2008. Akuntansi Biaya. Buku 1. Edisi Keempat Belas, Jakarta: Salemba Empat

Goleman, Daniel, $2003 . \quad$ Kepemimpinan yang Mendatangkan Hasil. Cetakan. Pertama. Jogjakarta: Amara Books

Halim, Abdul. 1996. Dasar - Dasar Akuntansi Biaya. Yogyakarta: PT BPFE

Halim, Abdul \& Supomo, Bambang. 2005. Akuntansi Manajemen. Yogyakarta: BPFE

Hanafi \& Halim, A. 2003. Analisis Laporan Keuangan. Edisi. Revisi. Yogyakarta: UPP AMP YKPN

Handoko, T. H. 2002. Manajemen; Edisi Kedua, Cetakan Ketigabelas. Yogyakarta: 
Harahap, Sofyan. 2001. Sistem Pengawasan Manajemen. Jakarta: Quantum

Harnato. 2003. Akuntansi Keuangan Menengah. Yogyakarta: BPFE

Jatmiko, Rohmad Dwi. 2005. Pengantar Bisnis. Edisi Pertama, Cetakan Kedua. Malang: Universitas Muhammadiyah Malang

Kotler, Philip. 2000. Prinsip - Prinsip Pemasaran Manajemen, Jakarta: Prenhalindo

Kotler, Philip, 2008. Manajemen Pemasaran, Edisi Milenium diterjemahkan Benyamin Molan. Jakarta: PT. Prenhallindo

Kotler \& Amstrong. 2001. Prinsip - Prinsip Pemasaran. Jilid I, Edisi kedelapan. Jakarta: Erlangga

Kotler, Philip \& Keller, Kevin Lane. 2010. Manajemen Pemasaran. Jilit 1, Edisi. Ketiga belas. Jakarta: Erlangga

Mardiasmo. 1999. Akuntansi Keuangan Dasar 1. Edisi Kedua. Yogyakarta: BPFE

Mulyadi. 2001. Sistem Akuntansi. Edisi Tiga. Jakarta: Salemba Empat

Mulyadi. 2002. Auditing. Edisi keenam, Cetakan pertama. Jakarta: Salemba Empat

Mulyadi. 2007. Sistem Perencanaan dan Pengendalian Manajemen. Jakarta: Salemba Empat

Mulyadi. 2012. Akuntansi Biaya. Edisi kelima. Yogyakarta: UPP STIM YKPN.

Nurdin Muh, dkk. 2008. Ilmu Pengetahuan Sosial 1. Jakarta: Pusat Pembukuan Departemen Pendidikan Nasional

Rahardjo, Budi. 2000. Keuangan dan Akuntans untuk Manajer Non Keuangan. Yogyakarta: Graha IImu

Rismiati, Catur \& Suratno, Bondan. 2001. Pemasaran Barang dan Jasa. Yogyakarta: Kanisius
Saladin, Djaslim. 2001. Manajemen Pemasaran, Analisis, Perencanaan, Pelaksanaan dan Pengendalian. Bandung: Lindakarya

Simamora, Henry. 2000. Manajemen Pemasaran Internasional. Jilid II. Jakarta: Salemba Empat

Sumayah. 2011. Pengaruh Volume Penjualan dan Biaya Produksi terhadap Laba Bersih (Studi Kasus pada PT Metrodata Electronics Tbk). Bandung: Jurnal Penelitian Universitas Komputer Indonesia Vol 4 (1): 1-12

Supriyono \& Riyanto, Bambang. 1992. Akuntansi Manajemen 1. Yogyakarta: BPFE

Supriyono, R. A. 1999. Akuntansi Biaya Buku I: Pengumpulan Biaya dan Penentuan Harga Pokok. Edisi 2. Cetakan Ke XII. Yogyakarta: BPFE

Suroto. 2000. Strategi pembangunan dan Perencanaan Perencanaan Kesempatan Kerja. Yogyakarta: Gajah Mada Univercity

Suzanti. 2009. Analisis Pengaruh biaya produksi dan penjualan Air bersih terhadap laba Bersih (Studi Kasus PT PDAM Tirtanadi). Yogyakarta: jurnal penelitian Universitas Siliwangi Vol 4 (1): 1-6

Swastha, Basu \& Irawan. 1990. Manajemen Pemasaran Modern. Yogyakarta: Liberty

1999. Manajemen Pemasaran Modern, Edisi 2. Yogyakarta: Liberty

Swastha, Basu. 2001. Manajemen Pemasaran I, Edisi Ketiga. Yogyakarta: BPFE

Swastha, Basu \& Irawan. 2005. Asas-asas Marketing. Yogyakarta: Liberty

Tjiptono, Fandy. 2008. Strategi Pemasaran. Edisi 3. Yogyakarta: ANDI

Winardi, J. 2005. Manajemen Perubahan (The Management of Change), Cetakan Ke-1, Jakarta: Prenada Media 
Ejournal Jurusan Pendidikan Ekonomi

Vol: 10 No: 2 Tahun: 2017 